\title{
Masa-Depan Cerah, Bahaya Menunggu: Negara-Bangsa Baru dan Kekerasan Massal di Asia Tenggara ${ }^{1}$
}

\author{
Henk Schulte Nordholt \\ KITLV, Leiden
}

\begin{abstract}
In this article the impact of the Cold War in Southeast Asia is evaluated. The region was turned into the hottest battlefields of this conflict which costed the lives of about seven million people. The Cold War also terminated fragile attempts to turn newly independent nation-states into democracies. Instead every country in Southeast Asia experienced authoritarian rule by either capitalist of socialist regimes. In the capitalist countries middle classes emerged which profited from economic growth under authoritarian rule. Since democracy was associated with instability and mass violence and economic growth with authoritarian rule, middle classes were very late in supporting new attempts to democratize their political systems.
\end{abstract}

Keywords: Cold War, Southeast Asia, mass violence, developmental state

\begin{abstract}
Dalam artikel ini, pengaruh Perang Dingin di Asia Tenggara dievaluasi. Kawasan ini berubah menjadi kawasan perang paling panas dalam konflik ini yang mengakibatkan kematian tujuh juta jiwa. Perang Dingin juga menghentikan usaha-usaha dalam mengembangkan negarabangsa yang baru merdeka ini menjadi demokrasi. Sebaliknya, setiap negara di Asia Tenggara mengalami pemerintahan otoriter baik lewat rezim kapitalis maupun sosialis. Dalam negaranegara kapitalis, kelas menengah muncul sebagai akibat dari pertumbuhan ekonomi dibawah pemerintahan otoriter. Karena demokrasi dihubungkan dengan imaji ketidakstabilan, kekerasan massal dan kekuasaan otoriter dengan imaji pertumbuhan ekonomi, kelas menengah yang muncul sangat lamban dalam mendukung usaha-usaha demokratisasi baru sistem politik mereka.
\end{abstract}

Kata kunci: Perang Dingin, Asia Tenggara, kekerasan massal, negara pembangunan

Artikel ini mencerminkan beberapa tema yang dijelaskan lebih mendetail dalam buku saya yang akan terbut berjudul Südost Asien yang merupakan bagian dari seri publikasi Neue Fischer Weltgeschichte (vol. 12), yang diterbitkan oleh S. Fischer Verlag di Frankfurt am Main. Ringkasan buku telah dipresentasikan di Seoul National University di bulan Mei 2014. Saya ingin mengucapkan terima kasih kepada kolega saya Dr. Keng We Koh yang memungkinkan kunjungan yang menggugah ini. 
Apabila fokus penelitian sejarah hanya ditunjukkan pada peristiwa politik menjelang pembentukkan negara-bangsa baru di Asia Tenggara pada akhir masa Perang Dunia Kedua, kita kadang lupa akan akibat jangka panjang dekolonisasi. Termasuk didalamnya hubungan yang bermasalah antara negara lama dengan bangsa baru, dan perbedaan kontras antara optimisme yang terpancar dari bangsa baru dan ledakan kekerasan masal yang terjadi dimana-mana. Dalam tulisan ringkas ini, saya bertujuan untuk meraba hubungan-hubungan ini dalam konteks Perang Dingin, yang mengubah kawasan ini menjadi kancah perang yang 'panas.'

Dekolonisasi politik di Asia Tenggara punya jalur yang berbeda, mengakibatkan hasil yang beragam dan meliputi periode yang lama. Pada tahun 1946 Filipina menjadi republik merdeka setelah negosiasi dengan Amerika Serikat, Birma mengikutinya pada tahun 1947 setelah tawar-menawar dengan Inggris; pada tahun 1945 nasionalis Indonesia dan Vietnam memproklamirkan kemerdekaan daripada republik masingmasing, walaupun kedaulatan secara formal diberikan oleh Belanda dan Perancis baru pada tahun 1949 dan 1954 setelah revolusi yang berat. Kemerdekaan kerajaan Kamboja dan Laos dari Perancis dinegosiasikan pada tahun 1954, dan Malaya - sebuah republik federal hibrid dibawah kedaulatan kesultanan masing-masing - menyusul pada tahun 1957 setelah proses negosiasi yang panjang dan bermasalah dengan Inggris. Pada tahun 1963, setelah serangkaian pembicaraan, Malaya berubah menjadi Federasi Malaysia ketika Serawak, Borneo Utara dan Singapura bergabung dalam negara-bangsa merdeka itu. Setelah muncul konflik mengenai posisi dominan elit Melayu, Singapura meninggalkan Federasi pada tahun 1965 dan menjadi kota-negara yang merdeka. Hanya negara kaya minyak Brunei dan Timor Leste yang miskin yang tetap bertahan sebagai titik-titik kolonial dibawah kontrol kolonial Inggris dan Portugis. Pada tahun 1984, Inggris mengabulkan kedaulatan utuh kepada kesultanan toriter di Brunei. Pada tahun 1975, Portugis yang semenjak tahun 1511 merupakan penakluk Eropa di Asia Tenggara pertama ketika menguasai Malaka, adalah kekuatan kolonial terakhir yang meninggalkan kawasan ini. Daripada memperoleh kemerdekaan, Timor Leste dijajah (ditaklukkan?) oleh Indonesia. Setelah perang gerilya yang berkepanjangan, Timor Leste mendapatkan kemerdekaannya pada tahun 2002 setelah Indonesia mengacaukan negara itu pada tahun 1999 dan PBB mendirikan pemerintahan sementara.

Kerajaan Thailand merupakan satu satunya daerah di kawasan ini yang tidak pernah dijadikan wilayah jajahan Barat. Walaupun mendapatkan tekanan yang besar dari Perancis dan Inggris dan dengan bayaran konsesi kawasan, ekonomi dan politik, Thailand berhasil mempertahankan kedaulatan formalnya. Pada 1946, Thailand secara resmi dimasukkan dalam 'keluarga bangsa-bangsa' ketika menjadi anggota dari PBB.

Persamaan yang menonjol diantara beragam negara-bangsa di Asia Tenggara adalah keberlanjutan dari perbatasan kolonial lama yang diarsir pada awal abad ke-20. Ketika Asia Selatan mengalami pemisahan berdarah pada tahun 1947, negara-negara baru di Asia Tenggara tetap melanjutkan kerangka perbatasan negara kolonial masing-masing. Dalam batas-batas ini ada keberagaman etnis dan agama yang besar. Khususnya di kepulauan Indonesia dan Filipina dan di Federasi Malaysia dimana kesatuan itu dipaksakan oleh negara kolonial. Berbeda dengan di kepulauan Asia Tenggara, di kawasan benua Asia Tenggara, kesatuan politik dibangun berdasarkan grup etnis inti (etnis 
Burma, Thai, Khmer, Lao dan Vietnam) dan akibat dari sejarah panjang pembentukan negara berdasarkan kerajaan dinastik yang menyebabkan proses perlahan asimilasi dan homogenisasi etnis, agama dan budaya (Lieberman, 2003 dan 2009). Penjajahan Jepang, revolusi dan efek berdarah dari Perang Dingin menciptakan persamaan lain di kawasan ini. Ia mengajarkan kepada aktoraktor politik bahwa konflik bisa diselesaikan lewat cara-cara yang penuh kekerasan dan mengakibatkan terjalinnya kekerasan menjadi bagian dari sistem politik di Asia Tenggara.

\section{Bangsa Baru dan Negara Lama}

Setelah kekacauan yang diakibatkan oleh penjajahan Jepang, yang menghentikan periode kolonial dan menyebabkan perluasan peperangan di seantero Asia Tenggara, bangsa-bangsa baru ini muncul sebagai alat guna mendorong modernitas. Mereka berfikiran ke masa depan dan menjanjikan perubahan, pembangunan dan perbaikan. Ada periode singkat semasa tahun 1950an dimana elit-elit nasional menunjukkan ketertarikan yang tinggi akan perkembangan baru diberagam tempat di dunia, yang dicirikan dari sikap keterbukaan yang luas. Terbebaskan dari ikatan rezim-rezim kolonial lama, elit-elit nasional memperluas garis pandang pada saat ketika ide-ide baru dibawa oleh koran, radio, musik, teater dan mewujudkan dirinya dalam arsitektur urban, pakaian dan bahasa (Lindsay dan Liem, 2012; Day dan Liem, 2004). Contoh kuat dari sikap ini dialami oleh kru film dari Amerika pada tahun 1953 di Bali. Ketika mereka bertanya akan lokasi terbaik guna merekam budaya tradisional Bali yang asli, jawaban orang Bali: "kenapa tidak rekam saja gedung pos kantor, rumah sakit dan sekolah-sekolah baru kami?" (Chegary, 1955: 129).

Negara telah memenangkan Perang Dunia Kedua dan dalam dunia sosialis dan kapitalis, negara dianggap sebagai motor utama untuk mewujudkan perubahan (Farabi Fakih, 2014). Di Asia Tenggara, negara merupakan lembaga-lembaga utama guna menstimulir proses pembentukkan bangsa, memperluas pendidikan dan bahasa nasional, menulis kembali sejarah nasional dan menciptakan simbol-simbol persatuan yang baru. Pemimpin-pemimpin nasionalis yang kharismatis seperti Presiden Sukarno di Indonesia, Perdana Menteri U Nu di Birma,

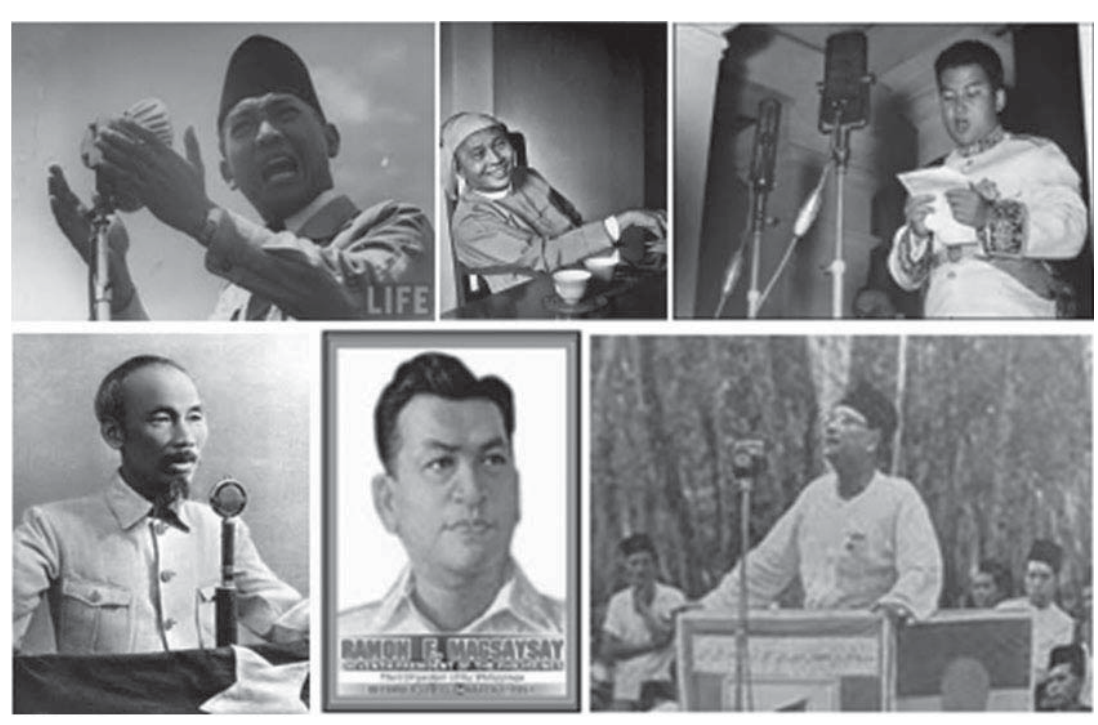

Sukarno, U Nu, Sihanouk, Ho Chi Minh, Magsaysay dan Tunku Abdul Rahman

Sumber: Disarikan dari Google Images.
Raja Sihanouk di Kamboja, Presiden Ho Chi Minh di Vietnam, Perdana menteri Tunku Abdul Rahman di Malay dan Presiden Magsasay di Filipina, mengejawantahkan optimisme baru, menjanjikan kemajuan dan mengarahkan warga mantan-koloni ini untuk menjadi partisipan aktif dalam bangsa mereka.

Negara kolonial yang diwariskan oleh pemimpin ini merupakan rezim-rezim terpusat yang dikuasai oleh orang asing yang dicurigai 
oleh pribumi dan bersekutu dengan elit lokal dan kelas kota terpelajar yang kecil. Fokus utama rezim-rezim ini ada pada eksploitasi sumber daya dan pengarahan tenaga kerja murah. Infrastruktur dibangun utamanya guna mendukung ekonomi kolonial, sementara investasi di bidang pendidikan dan kesehatan sangat terbatas. Kelompok minoritas pedagang asing menikmati hak istimewa ekonomi guna menghambat kemunculan borjuis pribumi. Tantangan utama yang dihadapi pemimpin nasionalis baru ada pada tiga bidang: (1) mengubah negara kolonial yang mereka wariskan dari alat represi menjadi lembaga yang bisa mendorong partisipasi populer; (2) mengubah ekonomi kolonial dari sifat eksploitasi menjadi mesin pembangunan, dan (3) mengubah masyarakat kolonial yang diwarnai pembatasan etnis dan agama menjadi bangsa yang satu.

Karena banyak birokrat tingkat menengah dan tinggi dididik dibawah kekuasaan kolonial, mereka melanjutkan sikap-sikap negara kolonial lama dalam negara-bangsa baru dan membentuk inti dari kelompok konservatif dalam negarabangsa baru ini. Lebih lanjut, militer dalam negara bangsa baru juga memperlihatkan kontinuitas yang sangat besar. Karena batasbatas koloinal tidak pernah dipermasalahkan sebagai akibat dari kesepakatan bersama antara pemegang kekuasan Barat, tentara kolonial punya tugas utama sebagai polisi yang menjamin keamanan internal negara terhadap pemberontak dan nasionalis. Di Vietnam dan terutama Birma dan Indonesia tentara nasional baru memiliki peranan penting dalam menggapai kemerdekaan dan akibatnya mereka mengklaim peran sebagai pelindung persatuan nasional. Setelah kemerdekaan mereka tetap melayani kepentingan negara dengan menekan segala tanda-tanda ketidaksetiaan (Anderson 1983).
Perekonomian dilemahkan dan infrastruktur rusak parah sebagai akibat dari krisis ekonomi tahun 1930an, penjajahan Jepang, revolusi dan pergantian rezim. Di Birma dan Indonesia, pabrik pengolahan minyak rusak, kota-kota seperti Manila dan Singapura hancur dan sektor ekspor ekonomi kolonial lumpuh. Walaupun ada pertumbuhan yang singkat pada awal tahun 1950an yang dirangsang oleh Perang Korea (1950-1953) tidak ada investasi ekonomi skala besar ataupun inovasi ekonomi lainnya. Usaha menjalankan kebijakan industrialisasi nasioinal lewat substitusi impor yang bertujuan mendorong produksi domestik barang-barang tertentu lewat penerapan tarif tinggi atas impor barang murah, berhasil sampai taraf tertentu di Filipina tapi gagal di Indonesia. Ekonomi Indonesia menjadi korban ketidak-efisiensi birokratis dan penyelundupan sementara diseluruh kawasan Asia Tenggara, jumlah populasi naik pesat ke level yang mengkhawatirkan, dari 177 juta pada tahun 1950 menjadi 295 juta pada tahun 1979.

Walaupun ada usaha memobilisasi populasi, sebagian besar politisi tidak punya banyak pengalaman dengan demokrasi dan mereka juga tidak tertarik untuk memperkuat partisipasi populer dalam proses pengambilan keputusan dan kontrol politik. Semenjak 1930an, Birma dan Filipina telah membatasi sistem pemerintahan dan pemilu, yang di Birma didominasi oleh elit terpelajar urban, sementara di Filipina dikontrol oleh elit mestizo pemilik lahan. Sebelum merdeka, demokrasi juga diperkenalkan di Malaya walaupun dipisah sesuai garis etnisitas dalam sebuah sistem yang didominasi oleh elit Melayu. Pemilu beguna untuk melegitimasi kekuasaan elit. Sebagian besar politisi dikawasan ini berbagi kekuasaan dengan birokrat gaya lama dan generasi baru pejabat pemerintahan modern yang punya keyakinan kuat bahwa populasi harus diarahkan 
dari sebuah tradisi kenegaraan yang statis menuju modernitas dan mereka percaya bahwa mereka dapat melakukan modernisasi kepada masyarakat hanya lewat cara yang top-down. Walaupun kenyataan bahwa negara-bangsa baru ini punya struktur administratif yang lemah, jaringan patronase politik sangat berakar dalam masyarakat. Di zaman pra-kolonial, penguasa dan pengikut mempertahankan hubungan-hubungan patronklien. Dimasa periode kolonial, sistem ini dipertahankan dalam pola penguasaan tidak langsung (indirect rule) yang menghubungkan penguasa Barat dan elit lokal. Setelah

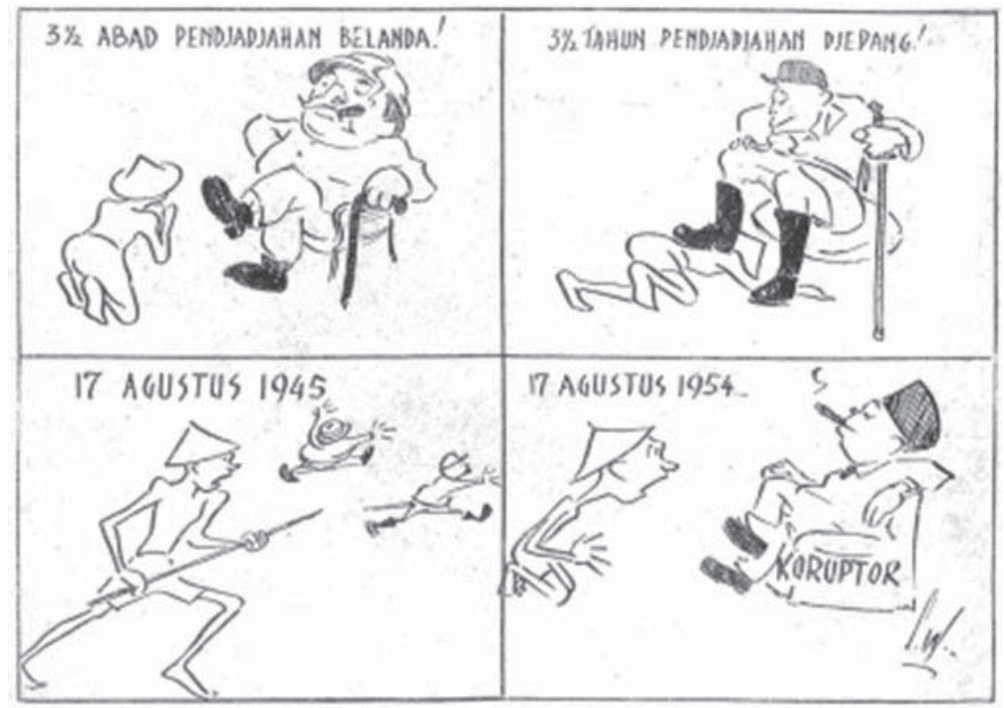

Karikatur yang satirikal menggambarkan perilaku penguasa dan perubahan rezim.

Sumber: Pemuda, 11 November 1954

merdeka, politisi mengambil alih peran dan membangun partai politik lewat jaringan klien baru yang dengan cepat menginfiltrasi ke birokrasi. (Schulte Nordholt, 2015).

Patronase, bukan demokrasi, yang menjadi ciri dari politik pasca-kolonial Asia Tenggara karena negara-bangsa baru tidak hanya dipersatukan lewat lembaga administratif formal tetapi bahkan lebih lewat jaringan patronase informal yang mengikat ibukota sampai ke desa-desa.
Tetapi, baik lembaga negara dan klien - yang karena sifatnya tidak memberi akses kepada non-klien - tidak mampu menghilangkan perasaan kekecewaan rakyat karena janjijanji bangsa baru tidak berhasil diwujudkan. Perasaan tidak puas populer meningkat dan membiakkan ketegangan-ketegangan etnis, agama dan kelas baru.

Ekonomi kolonial telah meningkatkan perbedaan antar kelas dan, sebagai akibat dari kekuasaan kolonial, kelompok dalam masyarakat dikategorisasi dan dipisahkan berdasarkan garis-garis etnis dan agama. Kelas, etnisitas dan agama menentukan batas ketegangan (fault lines) politik dalam masyarakat pasca-kolonial. Tidak lagi dibatasi oleh monopoli kekuasaan negara kolonial dan didorong oleh konflik-konflik baru, sentimen agama dan etnis dapat meledak dengan gampang ketika pemimpin baru memobilisir dukungan guna membuka akses mereka terhadap sumber daya negara yang terbatas pada saat ada ketidakpastian dan kekurangan. Secara bersamaan, ketidakpuasan terkait dengan eksploitasi dan pengucilan mendorong mereka yang miskin untuk mengorganisir diri mereka di bawah ideologi komunisme. Segera setelah Burma meraih kemerdekaannya pada tahun 1947, Burma mengalami serangkaian konflik etnis yang berlangsung hingga beberapa dekade. Pemuka suku Karen, Kachin, Chin, dan Shan berbalik melawan pemerintah pusat di Rangoon. Agama dan kelas juga memainkan peranan ketika kelompok muslim di Arakan dan faksi partai komunis melawan pemerintah pusat. Ketika komandan militer justru berubah menjadi pimpinan militer lokal, pemerintahan pusat hampir saja kolaps. 
Di Indonesia, agama, kelas, dan etnisitas turut memicu konflik politik selama periode revolusi dan tahun 1950an. Kristen Ambon dan kelompok muslim radikal di Jawa Barat mencoba untuk mendirikan negaranya sendiri, sementara pemberontakan PKI di Madiun berniat untuk mengubah ideologi Indonesia ke arah kiri, meskipun kemudian berakhir dengan kegagalan. Selama tahun 1950an, ketidakpuasan banyak pihak terhadap dominasi Jawa dan Suku Jawa dalam kancah perpolitikan Indonesia semakin meruncing, yang berimbas kepada meletusnya pemberontakan di Sumatra dan Sulawesi. Pada saat bersamaan pemerintah Indonesia menetapkan kebijakan untuk membatasi posisi ekonomi para pengusaha serta pedagang Tionghoa di Indonesia. Orang-orang gunung yang tinggal di daratan Asia Tenggara, serta suku-suku lokal yang tinggal di pedalaman Kalimantan, Papua, dan Semenanjung Malaya, semakin termarginalisasi. Para elit negara melihat rendang mereka dan bahkan mengkategorikan mereka sebagai kelompok terbelakang yang akan sangat sulit untuk dimodernisasi. Di Fi-lipina konflik antar kelas di tingkat desa mendorong terjadinya pemberontakan Hukbalahap di tahun 1940an. Pasca periode kolonial, minoritas Kristen di Asia Tenggara semakin terkucil; Orang-orang Katolik di Vietnam semakin terpinggirkan oleh rezim sosialis di Hanoi, sehingga mendorong terjadinya migrasi dalam jumlah besar ke Vietnam Selatan, dimana mereka bersekutu dengan pemerintahan Diem; namun setelah kemenangan rezim komunis pada tahun 1975, kembali mereka teralienasi. Para perantau yang berasal dari India dan Tiongkok yang sudah menetap sejak periode kolonial, semakin dibatasi pergerakannya dan menjadi 'orphans of empire' (Cribb dan Narangoa, 2004). Terbentuknya Malaya dan Federasi Malaysia jelas dipengaruhi oleh jurang perbedaan antara orang-orang Tiong- hoa dan Melayu. Negara harus mengatasi konflik-konflik tersebut dengan tujuan untuk mencapai kesatuan nasional yang baru. Namun seringkali tindakan-tindakan represif yang menjadi ciri khas negara kolonial, masih diterapkan oleh negara merdeka tersebut.

\section{Ketika Perang Dingin Memanas: Keke- rasan Massal dan Pembantaian}

Berbeda dengan pembentukan negara, proses urbanisasi, industrialisasi, dan demokratisasi di Eropa yang memakan waktu 1,5 abad bahkan hingga dewasa ini, seluruh fenomena tersebut berlangsung di Asia Tenggara dibawah tekanan kuat dalam jangka waktu beberapa dekade. Sebagian besar negara di Asia Tenggara hanya mengalami fase pemerintahan demokratis singkat setelah kemerdekaan. Pada tahun 1947 kudeta militer membatalkan pemerintahan demokratis di Thailand yang rentan; di tahun 1959 Soekarno dengan dukungan militer memutuskan untuk membubarkan parlemen dan memperkenalkan konsep 'Demokrasi Terpimpin' yang kelak turut memuluskan rezim pemerintahan otoriter Soeharto, pengganti Soekarno; di tahun 1962 Jenderal Ne Win mendirikan rezim militer di Burma; setahun kemudian kudeta militer mengakhiri kekuasaan presiden Ngo Dinh Diem di Vietnam Selatan; di tahun 1970 Jenderal Lon Nol menggantikan konsep 'one party kingdom' Sihanouk dengan rezim militer di Kamboja; Laos sudah telanjur masuk ke dalam peperangan permanen sebagai akibat dari pemilihan umum dan matinya parlemen; di tahun 1972 Presiden Marcos mengakhiri sistem demokrasi parlementer di Filipina dan mendirikan sebuah rezim otoriter. Hanya Federasi Malaysia dan Singapura - dan juga Indonesia ketika berada dibawah rezim Soeharto mulai tahun 1971 - yang mempertahankan demokrasi elektoral di bawah kebijakan otoriter 'satu partai' (UMNO - Malaysia; PAP 
- Singapura; dan Golkar - Indonesia). Vietnam Utara, dan sejak 1975 seluruh Vietnam, Kamboja, dan Laos, menerapkan 'one party states' yang berlandaskan sosialisme.

Kemunduran demokrasi di Asia Tenggara berbarengan dengan kemunculan Perang Dingin di Asia Tenggara. Kawasan ini berubah menjadi arena peperangan terbesar dari Perang Dingin, yang kemudian termanifestasikan dalam perang yang 'panas' dan berdarah antara Amerika, Uni Soviet, dan RRT, yang berupaya untuk memperluas dan menjaga pengaruh mereka dalam perpolitikan dunia. Sebagai konsekuensi dari artikulasi dan ketegangan internasional dalam negara-negara pasca kolonial, rangkaian konflik kemudian berkembang dan memasuki arena kekerasan yang lebih luas.

Terhitung sejak tahun 1945 Amerika berupaya mengidentifikasi ancaman komunis di Asia Tenggara. Untuk alasan itu, pemberontakan Hukbalahap di Filipina segera dilabeli sebagai pemberontakan komunis. Menjelang akhir 1960an, the Maoist New People's Army terus melanjutkan perang gerilya dalam lingkup kecil yang juga diikuti dengan pemerasan. Kudeta militer di Thailand pada tahun 1947 mendapat dukungan penuh dari Amerika karena pemegang tampuk kekuasaan yang baru di Thailand dinilai sebagai pendukung anti-komunis. Pasukan bersenjata Burma menerima dukungan penuh dari negaranegara Barat dalam upaya mereka untuk memerangi pasukan gerilya komunis dan mencegah invasi dari komunis Tiongkok.

Titik tolak yang mempercepat Perang Dingin adalah Konferensi Pemuda Asia Tenggara yang dihelat di Calcutta di tahun 1948, setelah rangkaian pemberontakan komunis yang meletus di berbagai negara. Situasi darurat pecah pada tahun 1948 di Malaya ketika orang-orang Tionghoa yang berhaluan komunis memberontak melawan pemerintah kolonial Inggris dan elit-elit Melayu. Karena para pemberontak gagal untuk menjangkau kelompok lainnya, konflik tersebut kemudian kerap dikerucutkan sebagai konflik kelas antara TionghoaMelayu. Di Singapura Lee Kuan Yuew memutuskan untuk menjalin kerjasama dengan Malaya guna menangkal infiltrasi komunis di Singapura. Aliansi itu sendiri kemudian berakhir di tahun 1965 karena konflik dengan Federasi Malaysia (Cheah Boon Kheng, 2008). Juga di tahun 1948 ketika pimpinan PKI, Musso, diinstruksikan oleh Moskow untuk mengambilalih revolusi Indonesia. Pemberontakan pun pecah di Madiun, yang kemudian berhasil ditumpas oleh Tentara Republik dengan bantuan Amerika. Sejak 1949 hingga sekarang revolusi yang terjadi di Vietnam diatur dengan ketat oleh partai komunis, dimana golongan non-komunis dipinggirkan. Sementara itu di Laos, pergerakan oposisi Pathet Lao berubah menjadi pasukan gerilya yang berideologi 'kiri'. Pathet Lao memutuskan untuk bersekutu dengan Vietnam Utara, sementara pada saat bersamaan Amerika berupaya untuk mengontrol pusat pemerintahan Laos dari Vientiane.

Kemunculan kembali Partai Komunis Indonesia di panggung politik Indonesia pada awal tahun 1950an, membuat golongan Muslim dan juga militer Indonesia bersikap waspada. Presiden Soekarno melalui Konferensi Asia-Afrika di Bandung di tahun 1955, menyatakan keinginannya untuk membentuk 'Third Way' sebagai alternatif dan solusi netral dari Perang Dingin yang memecah politik dunia ke dalam Blok Barat dan Blok Timur. Konferensi tersebut ternyata tetap tidak mampu mencegah penyebaran kekerasan politik dan massal di Asia Tenggara.

Perang di kawasan Indochina yang berlangsung sejak tahun 1954 hingga 1975 
merupakan peperangan terbesar dan terkejam yang pernah terjadi di kawasan daratan Asia Tenggara. Vietnam Utara melancarkan perang gerilya melawan Vietnam Selatan yang disokong oleh sekitar 500.000 tentara Amerika di tahun 1969. Peperangan juga menjalar ke negara tetangga seperti Laos dan Kamboja, dimana konflik lokal kemudian berkembang menjadi perang dalam skala besar. Untuk menghentikan infiltrasi Vietnam Utara ke Vietnam Selatan, Amerika membombardir jalur gerilya Ho Chi Minh yang terbentang dari Vietnam Utara melewati Laos dan Kamboja. Tindakan Amerika tersebut ternyata membawa malapetaka. Sebagai perbandingan, Amerika menjatuhkan lebih banyak bom di Laos dibandingkan dengan Sekutu ketika membombardir Jerman selama Perang Dunia II. Konflik itu juga berimbas terhadap situasi politik di Indonesia, dimana meletus sebuah peristiwa yang dinamakan 'Gerakan 30 September 1965', yang diikuti dengan pembantaian besarbesaran oleh militer dan milisi Muslim terhadap mereka yang dituduh sebagai komunis. Pembantaian tersebut - meskipun latarbelakangnya berkebalikan dengan peristiwa 1965 di Indonesia - mirip dengan apa yang terjadi di Kamboja setelah Khmer Rouge me-ngambil alih kekuasaan di tahun 1975. Dalam kedua kasus tersebut rezim kekuasaan lama sudah kolaps, sehingga rezim baru kemudian mendirikan rezimnya sendiri yang ditandai dengan pembasmian lawanlawan politiknya dengan cara yang sadis, di Indonesia adalah komunis, sementara di Kamboja adalah kaum intelektual dan kelas menengah. Pembersihan tersebut bisa terwujud berkat persetujuan dan dukungan dari negara superpower, yang mendukung rezim baru tersebut (Amerika di Indonesia dan Tiongkok di Kamboja). Tidak bisa di- pungkiri bahwa pimpinan Khmer Rouge, Pol Pot, mengetahui nasib partai komunis di Indonesia dekade sebelumnya -PKI saat itu merupakan partai komunis terbesar di dunia di luar blok komunis- yang mungkin semakin mendorong Pol Pot untuk memusnahkan segala macam hal yang berpotensi untuk mengganjal pemerintahannya, sebagai langkah untuk menghindari serangan balik (Fein, 1993).

Jatuhnya Saigon pada bulan April 1975 memunculkan dua akibat. Kudeta militer di Thailand pada bulan Oktober 1976 membawa Thailand kepada fase demokrasi yang singkat dengan pemilihan umum yang tidak jelas dan koalisi yang rentan (19731976). Instabilitas ekonomi dan ketakukan akan invasi komunis, turun berperan dalam menciptakan aliansi antara militer, kelas menengah, dan juga monarki. Hal ini meresmikan sebuah periode baru dari rezim pemerintahan otoriter, dimana banyak kelompok kiri pindah ke daerah pegunungan dan memulai perjuangan bersenjata. Pada bulan Desember 1975 Tentara Indonesia, dengan dukungan Amerika, menginvasi Timor Leste sesudah Portugal memutuskan untuk mengakhiri kolonialismenya di sana. Karena ketakutan bahwa Timor Leste akan berkembang sebagai pos strategis dari komunisme Tiongkok. Pertempuran sipil pun pecah dan meluas ke dalam arena geopolitikal, dengan konsekuensi yang tragis bagi para penduduk lokal.

Jumlah korban Perang Dingin di Asia Tenggara tidak pernah diketahui secara rinci. Namun berdasarkan perhitungan kasar, sekitar 5-7 juta orang menjadi korban, sebanding dengan jumlah korban Holocaust di Eropa selama Perang Dunia II. ${ }^{2}$

Vietnam-Laos: 2-4 juta; Kamboja: 2 juta; Indonesia: 0,5-0,7 juta; Timor Leste: 0,1-0,15 juta; Malaysia, Filipina, Burma, Thailand: sekitar 4 juta. Cf. Taylor, 2013, Kiernan, 2008, Crib, 1990, Van Klinken, 2012, Harper, 1999, Kerkvliet, 2002, Taylor, 2009, Baker dan Pasuk Phonghpaichit, 2014. 


\section{Rezim otoriter baru}

Ketika tahun 1950 sebagian besar bangsa muncul sebagai negara demokrasi baru, maka di pertengahan 1970-an sebagian besar dari negara-negara tersebut mengalami kekerasan massal dan berada di bawah rezim pemerintahan otoriter. Thailand (sejak 1976), Burma dan Vietnam Selatan (hingga 1975) merasakan rezim militer; Indonesia mengalami fase pemerintahan otoriter yang dikendalikan oleh militer; Filipina, Malaysia dan Singapura merasakan rezim otoriter sipil; sedangkan dari 1975 sampai sekarang Vietnam, Kamboja, dan Laos dikendalikan oleh rezim otoriter sosialis.

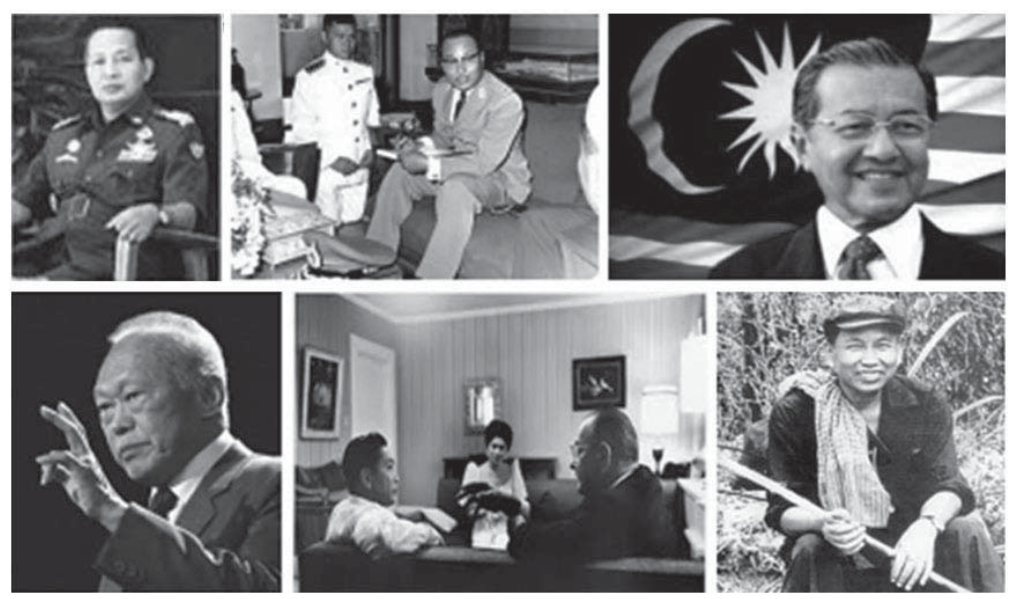

Suharto, Ne Win, Mahathir, Lee Kuan Yew, Marcos dan istrinya bertemu dengan Presiden Johnson, Pol Pot

Sumber: Disarikan dari Google Images

Dengan berkiblat ke Soviet dan Tiongkok, rezim sosialis menekankan pada kolektivisme pertanian dan investasi di sektor industri berat. Namun negara-negara ini mengalami kemerosotan ekonomi yang disebabkan oleh mandeknya sistem birokrasi dan juga keterbatasan untuk berinovasi. Faksionalisme dan hubungan patron-klien menjadi ciri utama bila melihat hubungan internal antar partai politik dan antara partai dengan militer.

Sejak tahun 1970an hingga sekarang para kapitalis berperan dalam mempercepat pertumbuhan ekonomi di kawasan tersebut. Didukung oleh pinjaman dalam jumlah besar dari Amerika, Jepang, dan IMF, sehingga membuat aliansi para birokrat, politikus, dan pengusaha berkecimpung di dalam sebuah sistem yang disebut sebagai 'authoritarian developmental states.' Salah satu kunci untuk menyeimbangkan pertumbuhan tersebut adalah dengan menerapkan sebuah kebijakan yang dinamakan Revolusi Hijau. Dengan dukungan dana dari Rockefeller dan Ford Foundations, the International Rice Research Institute di Filipina mampu membudidayakan varietas beras baru dengan hasil produksi yang lebih tinggi. Hasil dari riset tersebut ditujukan untuk menyuplai makanan ter-hadap populasi yang terus meningkat dan juga untuk mencegah semakin meluasnya 'Revolusi Merah'.

Pertumbuhan ekonomi juga berbanding lurus dengan perkembangan kelas menengah yang dibesarkan, disosialisasikan, dan - sebagian besar - didanai oleh negara. Sebagai gantinya, mereka menunjukkan loyalitas mereka terhadap pemegang tampuk kekuasaan. Berbanding terbalik dengan sejarah Eropa dimana kelompok kelas menengah berperan sebagai agen utama dalam proses demokratisasi, kelompok kelas menengah di Asia Tenggara cenderung menguntungkan dan mendukung rezim otoriter yang berkuasa. Dengan memori kekerasan yang masih segar dalam ingatan mereka, sebagian besar dari mereka merindukan stabilitas dan pertumbuhan ekonomi, yang menjadi pondasi solid bagi rezim otoriter. Atau dalam bahasa lain: selama rezim ini menguntungkan. Ketika Marcos dan Suharto gagal mempertahankan kekuasaannya, demonstrasi besarbesaran kemudian mengakhiri kekuasaan mereka masing-masing di tahun 1986 dan 
1998. Kondisi serupa juga terjadi di bekas negara-negara sosialis (termasuk Burma), dimana rezim otoriter masih berkuasa, namun kelas menengah yang masih loyal memanfaatkan kondisi tersebut untuk membuka market-market baru. Gelombang baru demokratisasi yang muncul menjelang akhir abad ke-20, dan berbarengan dengan runtuhnya tembok Berlin serta berakhirnya Perang Dingin, tidak lagi menguntungkan rezim otoriter dan anti-komunis. Sebaliknya, proses demokratisasi dan desentralisasi menandai hubungan-hubungan politik baru di antara negara-negara tersebut.

Kekerasan massal yang dipicu oleh perang dingin telah merubah pemikiran politik di Asia Tenggara menjadi lebih fundamental. Negara-negara demokratis baru, namun lemah digantikan oleh rezim otoriter yang lebih kuat pada tahun 1950an. Mereka menggabungkan berbagai bentuk kekerasan politik, merubah represi politik menjadi milisi sipil. Intimidasi kekerasan tetap menjadi bagian dari sistem politik. Setelah tertunda selama beberapa dekade, proses demokratisasi baru-baru ini diinisiasi. Namun jalan dan upaya untuk mewujudkan demokratisasi kelembagaan, termasuk juga akuntabilitas dari pemegang kekuasaan, masih panjang dan berliku.

\section{Bibliografi}

Anderson, Benedict. 1983. "Old State, New Society: Indonesia's New Order in Comparative Historical Perspective," The Journal of Asian Studies 42: 477-496.

Baker, Chris dan Phonghpaichit, Pasuk. 2014. A History of Thailand. Cambridge: Cambridge University Press. Third Edition.

Cheah Boon Kheng. 2002. Malaysia: The Making of a Nation. Singapore: ISEAS.
Chegary, Jacques. 1955. Bliss in Bali. The Island of Taboos. London: Arthur Barker.

Cribb, Robert (ed.). 1990. The Indonesian Killings 1965-1966: Studies from Java and Bali. Clayton: Monash Centre of Southeast Asian Studies.

Cribb, Robert, dan Narangoa, Li. 2004. "Orphans of Empire: Divided Peoples, Dilemmas of Identity, and Old Imperial Borders in East and Southeast Asia," Comparative Studies in Society and History 46: 164-187.

Day, Tony dan Liem, Maya. 2004. Cultures at War. The Cold War and Cultural Expression in Southeast Asia. Ithaca: Southeast Asia Program.

Farabi Fakih. 2014. The Rise of the Managerial State in Indonesia. PhD thesis Leiden University.

Fein, Helen. 1993. "Revolutionary and Antirevolutionary Genocides: A Comparison of State Murders in Democratic Kampuchea, 1975 to 1979 , and in Indonesia, 1965 to 1966," 35: 796823. Comparative Studies in Society and History

Harper, Tim. 1999. The End of Empire and the Making of Malaya. Cambridge: Cambridge University Press.

Kerkvliet, Ben. 2002. The Huk Rebellion: A Study of Peasant Revolt in the Philippines. Lanham: Rowman and Littlefield.

Kiernan, Ben. 2008. The Pol Pot Regime. Race, Power, and Genocide in Cambodia under the Khmer Rouge, 1975-79. New Haven: Yale University Press. Third Edition.

Klinken, Gerry van. 2012. "Death by Deprivation in East Timor 1975- 
1980," Reinventing Peace, World Peace Foundation. http://sites.tufts.edu/ reinventingpeace/2012/04/17/death-bydeprivation-in-east-timor-1975-1980/.

Lieberman, Victor. 2003 dan 2009. Strange Parallels. Southeast Asia in Global Context ca. $800-1830.2$ vols. Cambridge: Cambridge University Press.

Lindsay, Jennifer dan Liem, Maya (eds). 2012. Heirs to World Culture. Being Indonesia 1950-1965. Leiden: KITLV Press.
Schulte Nordholt, Henk. 2015. "From Contest State to Patronage Democracy: the Longue Durée of Clientelism in Indonesia', David Henley dan Schulte Nordholt, Henk (eds). Environment, Trade and Society in Southeast Asia. A Longue Durée Perspective. Leiden: Brill/ KITLV. hlm. 166-180

Taylor, Keith. 2013. A History of the Vietnamese. Cambridge: Cambridge University Press.

Taylor, Robert. 2009. The State in Myanmar. London: Hurst. 
